\title{
ПСИХОЛОГІЧНІ ОСОБЛИВОСТІ ФОРМУВАННЯ ПОЗИТИВНОГО ПСИХОЛОГІЧНОГО КЛІМАТУ В КОЛЕКТИВІ СТУДЕНТІВ-МЕДИКІВ
}

\author{
ДВНЗ «Івано-Франківський національний медичний університет», м. Івано-Франківськ, Україна
}

\begin{abstract}
Мета: дослідити та виявити психологічні особливості формування позитивного психологічного клімату в колективі, зокрема у колективі студентів-медиків.

Матеріали і методи. Для оцінювання деяких основних проявів психологічного клімату в колективі ми скористалися картою-схемою Л. Н. Лутошкина. В експерименті взяв участь 31 студент-медик.

Результати. Розглядаючи окремо показники кожного студента-медика можна в контрольній групі виявити декілька низьких результатів. У контрольній групі були такі студенти-медики, які у відповідях на питання зазначали, що, швидше за усе, перейшли б в іншу групу, і оцінювали взаємини у своїй групі гірше, ніж у більшості колективів. У експериментальній групі в основному студенти-медики набирали високі бали і у відповідях вказували, що хотіли б залишитися навчатися у своєму колективі, а також високо оцінювали взаємини між членами своєї групи.

Висновки. Соціально-психологічний клімат - це психологічний настрій в групі, який відображає характер взаємин між людьми. Сприятлива атмосфера не лише продуктивно впливає на їі результати, але і перебудовує людину, формує у неї нові можливості й проявляє потенціал. У зв'язку з цим, виникає необхідність в оптимізації стилю міжособистісної взаємодії в студентів-медиків.
\end{abstract}

КЛЮчОВІ СЛОВА: психологічний клімат; колектив; чинники психологічного клімату.

В умовах сучасної науково-технічної революції постійно зростає інтерес до явища соціальнопсихологічного клімату в колективі. Актуальність цієї проблеми диктується передусім збільшеними вимогами до рівня психологічної включеності індивіда в його діяльність і постійним зростанням особистісних вимог. Формування позитивного соціально-психологічного клімату студентського колективу $€$ однією 3 важливих умов досягнення зростання продуктивності праці й якості навчання. Від рівня соціально-психологічного клімату кожного окремого студентського колективу залежить загальна соціально-політична, ідеологічна атмосорера суспільства та країни в цілому.

Мета дослідження: дослідити та виявити психологічні особливості фрормування позитивного психологічного клімату в колективі, зокрема у колективі студентів-медиків.

Матеріали і методи. Теоретичну основу дослідження склали психолого-педагогічні праці, пов'язані з цією проблемою, а саме: основні положення психології малих соціальних груп (Г. М. Андреєва, А. І. Донцов, Е. І. Кричевський, Н. Н. Обозів, В. П. Позняков, Л. Г. Почебут, В. А. Чикер, Н. І. Шевандрин та ін.); психологія спілкування і міжособистісних взаємин (В. С. Агеев, Ю. М. Жуків, Я. Л. Коломинський, В. Г. Крисько, А. С. Морозів, Р. І. Мокшанцев, А. А. Петрівська, Е. Н. Різників та ін.).

Для оцінювання основних (емоційні, поведінкові та когнітивні) проявів психологічного клімату в колективі ми скористалися картою-схемою (с) Т.Л. Ленчук, 2017
Л. Н. Лутошкина. В експерименті взяв участь 31 студент-медик. Було сорормовано дві групи: а) основна група (або основна вибірка) та б) контрольна група (або контрольна вибірка). Студенти основної групи брали участь у всіх процедурах експерименту та проходили цикл фрормуючих впливів, що поєднували процедури різного характеру: навчальні, ігрові, практичні та роботу в групах. Членів контрольної групи розглядали як еталон, взірець, за яким оцінювали розвиваючий та фрормуючий ефект. Усім досліджуваним були надані листки, де в лівій стороні описані ті якості колективу, які характеризують позитивний психологічний клімат, у правій - якості колективу 3 явно несприятливим кліматом. Міру вираження тих або інших якостей визначають за допомогою семибальної шкали, розміщеної в центрі листка (від +3 до -3), а саме такі якості: настрій колективу, взаєморозуміння, позитивне ставлення один до одного, співпереживання за участь в спільних справах, підтримка, повага, принцип «один за всіх і всі за одного», активність, гордість за колектив.

Результати дослідження та їх обговорення. Психологічний клімат у колективі студентів-медиків мав нестійкий характер, з переважанням не зовсім сприятливих взаємин її членів. Необхідно сказати, що студенти-медики не можуть точно визначити характер емоційної взаємодії всередині колективу; позитивно оцінили емоційний стан всередині групи - 40 \% - це означало, що вони вважали взаємини позитивними; негативну відповідь дали 48 \% студентів, що засвідчувало наявність 
у внутрішньогрупових стосунках антипатії. 8 \% вважали, що обмін інформацією не має чіткого напряму, або погано налагоджений; 48 \% студентівмедиків відзначили, що наявний обмін досвідом та знаннями у сорері діяльності, співпраця всередині колективу налагоджена добре; 44 \% вважали, що інфрормаційний обмін у групі слабкий або відсутній взагалі. Так само 8 \% студентів-медиків зауважили, що поведінку співробітників не можна назвати такою, що повністю відповідає очікуванням один одного; позитивно оцінили поведінку своїх одногрупників 52 \% опитуваних, що означало, що поведінка повністю відповідала їх очікуванням; негативний поведінковий компонент відзначали 40 \% студентів-медиків. У результаті дослідження були виявлені статистично значущі відмінності за наступними показниками:

1) за показником «Прагнення до збереження цілісності групи». Студенти експериментальної групи оцінювали своїх одногрупників за цим показником у середньому вище порівняно із одногрупниками контрольної групи ( $\leq \leq 0,01)$. У студентів експериментальної групи частіше спостерігали такі оцінки, як «усі» або «майже всі». Для членів експериментальної групи більше важливо, ніж для членів контрольної групи працювати в незмінному складі;

2) за показником «Згуртованість». В експериментальній групі майже усі студенти відзначають, що для більшості учасників їх зміни характерні схожі переконання, схожі оцінки проблем, які панують у колективі студентів-медиків. Члени експериментальної групи знаходять більше спільного між собою, ніж члени контрольної групи (p $\leq 0,01)$;

3) за показником «Контактність (особистісні взаємини)». Студенти-медики експериментальної групи оцінювали розвиток особистістих взаємин у своїй групі вище, ніж студенти-медики контрольної групи (p $\leq 0,01)$;

4) за показником «Відкритість». В експериментальній групі студенти-медики оцінюють своїх одногрупників як доброзичливих до себе і до інших членів групи, а так само і до студентів іншої групи ( $\leq \leq 0,05)$;

5) за показником «Організованість». Студенти-медики експериментальної групи відзначають, що всі або майже всі одногрупники вміло взаємодіють один з одним, безконорліктно розподіляють обов'язки між собою, швидко знаходять спільну мову. Для студентів-медиків контрольної групи характерні в середньому нижчі оцінки своїх колег за цими показниками, такі як «половина», «меншість» $(p \leq 0,01)$;

6) за показником «Інформованість». Члени експериментальної групи вважають, що для всіх або для більшості їх одногрупників характерне знання рис вдачі один одного, знання, як йдуть справи один у одного;

7) за індексом групової згуртованості Сишора. Значення індексів групової згуртованості в експериментальній групі перевищує значення в контрольній групі ( $\leq \leq 0,01)$.

Розглядаючи окремо показники кожного студентамедика можна в контрольній групі виявити декілька низьких результатів. У цій групі були такі студенти-медики, які у відповідях на питання зазначали, що, швидше за усе, перейшли б в іншу групу, і оцінювали взаємини у своїй групі гірше, ніж у більшості колективів. У експериментальній групі в основному студенти-медики набирали високі бали і при відповідях на питання відповідали, що хотіли б залишитися навчатися у своєму колективі, а так само високо оцінювали взаємини між членами своєї групи. Не виявлено статистично значущих відмінностей за показником «Відповідальність» в контрольній і експериментальній групах. Студенти-медики цих груп, в середньому, за цим показником, однаково оцінювали своїх одногрупників. В основному, при оцінці за кожним цим показником користувалися такими оцінками, як «більшість» або «половина». У відповідях на питання за цим показником члени експериментальної і контрольної груп відповідали, що не для усіх їх одногрупників характерно підтверджувати свої слова справою, об'єктивно оцінювати свої успіхи і невдачі, відповідально виконувати будь-яку роботу. Це пояснюється тим, що студенти-медики, і контрольної і експериментальної груп, не досягли своєї «зрілості» і не можуть бути названі командою, найважливішою характеристикою якої якраз і $€$ розподіл відповідальності між усіма членами команди заради досягнення кінцевого результату командної роботи, тоді як кожен несе індивідуальну відповідальність за частину загального результату.

\section{Висновки}

Характер соціально-психологічного клімату в цілому залежить від рівня групового розвитку. Ми також встановили, що між станом соціальнопсихологічного клімату розвиненого колективу і ефективністю спільної діяльності його членів існує позитивний зв'язок. Клімат залежить від хороших, доброзичливих стосунків, посилюється позитивною мотивацією студентів-медиків, взаємоповагою, успішним керівництвом, хорошими внутрішньогруповими комунікаціями, співпрацею, взаємодопомогою.

Перспективи подальших досліджень. Подальше дослідження психології взаємин у студентських колективах дозволить значимо підняти ефективність навчання у вищому навчальному закладі.

\section{Список літератури}

1. Морозова Г. Б. Психологическое сопровождение организации и персонала / Г. Б. Морозова. - СПб. : Речь, 2012. - $400 \mathrm{c}$.

2. Психологія менеджменту / за ред. А. В. Карпова. - М. : Гардарика, 2007. - 584 с. 
3. Підприємництво: психологічні, організаційні та економічні аспекти : навч. посіб. / А. А. Мазаракі, С. Д. Максименко,

Л. П. Кулаківська, Т. Ю. Кулаківський. - К. : Київ. нац. торг.-економ. університет, 2012. - 720 с.

4. Конфрликты / под ред. Л. Ю. Субботиной. - Ярославль : Академия розвития, Академия Холдинг. - 2001.

5. Корольчук М. С. Психофрізіологія діяльності / М. С. Корольчук. - К. : Ельга, Ніка-Центр, 2004. - 400 с.

6. Утлик Э. П. Организационные традиции и организационная культура / Э. П. УТлик // Актуальные вопросы управления : тематический сборник научных трудов. Вып. 2 ; за ред. А. В. Филиппова. - М., 1999. - С. 3-17.

7. Платонов Ю. П. Психологія колективної діяльності : теоретико-методологічний аспект / Ю. П. Платонов. - Л. : вид-во лДУ, 1990. - 181 с.

\section{References}

1. Morozova H.B. (2012) Psikhologicheskoe soprovozhdieniye organizatsii i personala [Psychological support of the organization and staff]. Moscow: Rech [in Russian].

2. Karpova, A.V. (2007). Psykholohiia menedzhmentu [Psychology of management ]. Moscow: Hardarika [in Ukrainian].

3. Mazaraki, A.A., Maksymenko, S.D., Kulakivska, L.P., Kulakivskyi, T.I. (2012). Pidpryiemnytstvo: psykholohichni, orhanizatsiini ta ekonomichni aspekty [Entrepreneurship: psychological, organizational and economic aspects]. Kyiv: Nats. torh.-ekonom. un-t [in Ukrainian]

4. Subotina, L.I. (2001). Konflikty [Conflicts]. Iaroslavl: Akademiia rozvytku [in Ukrainian]

5. Korolchuk, M.S. (2004). Psykhofiziolohiia diialnosti [Psychophysiology of activity]. Kyiv: Elha, Nika-Tsentr [in Ukrainian]. 6. Utlyk, E.P. (1999). Orhanizatsiini tradytsii i orhanizatsiina kultura. Aktualni pytannia upravlinnia [Organizational traditions and organizational culture. Current issues of management]. Zbirka naukovykh prats. Moscow [in Ukrainian].

7. Platonov, I.P. (1990). Psykholohiia kolektyvnoi diialnosti: Teoretyko- metodolohichnyi aspekt [Psychology of collective activity: Theoretical and methodological aspect ]. Lviv: vyd-vo LDU [in Ukrainian].

\section{ПСИХОЛОГИЧЕСКИЕ ОСОБЕННОСТИ ФОРМИРОВАНИЯ ПОЛОЖИТЕЛЬНОГО ПСИХОЛОГИЧЕС- КОГО КЛИМАТА В КОЛЛЕКТИВЕ СТУДЕНТОВ-МЕДИКОВ}

Т.Л. Ленчук

ГВУЗ «Ивано-Франковский национальный медицинский университет», г. Ивано-Франковск, Украина

Цель: изучить и выявить психологические особенности формирования положительного психологического климата в коллективе, в частности в коллективе студентов-медиков.

Материалы и методы. Для оценки некоторых основных проявлений психологического климата в коллективе мы воспользовались картой-схемой Л. Н. Лутошкина. В эксперименте принял участие 31 студент-медик.

Результаты. Рассматривая отдельно показатели каждого студента-медика можно в контрольной группе выявить несколько низких результатов. В контрольной группе отдельные студенты-медики в ответах на вопросы отвечали, что, скорее всего, перешли бы в другую группу, и оценивали отношения в своей группе хуже, чем в большинстве коллективов. В экспериментальной группе в основном студенты-медики набирали высокие баллы и при ответах на вопросы отвечали, что хотели бы остаться учиться в своем коллективе, а так же высоко оценивали отношения между членами своей группы.

Выводы. Социально-психологический климат - это психологический настрой в группе, который отражает характер взаимоотношений между людьми. Благоприятная атмосфера не только продуктивно влияет на ее результаты, но и перестраивает человека, фрормирует у него новые возможности и проявляет потенциал. В связи с этим, возникает необходимость в оптимизации стиля межличностного взаимодействия у студентов-медиков.

КЛЮЧЕВЫЕ СЛОВА: психологический климат; коллектив; факторы психологического климата.

\section{PSYCHOLOGICAL PECULIARITIES OF THE FORMATION OF A POSITIVE PSYCHOLOGICAL CLIMATE IN A GROUP OF MEDICAL STUDENTS}

T.L. Lenchuk

Ivano-Frankivsk National Medical University, Ivano-Frankivsk, Ukraine

Purpose: to study the psychological peculiarities of formation of positive psychological climate in the collective; identify the psychological features of the formation of a positive psychological climate; to develop practical recommendations for the formation of a positive climate in the staff of medical students.

Materials and Methods. To evaluate some of the main manifestations of the psychological climate of the team, we used the map-scheme of L.N. Lutoshkina. The experiment was attended by 31 medical students. They were given letters, where the left side describes the qualities of the team that characterize the positive psychological climate, in the right - the quality of a team with a clearly unfavorable climate.

Results. By considering separately the indicators of each medical student, one can detect several low results in the control group. In the control group there were such medical students who responded to the questions that they most likely would have switched to another group and assessed the relationships in their group worse than most of the teams. In the experimental group, mainly medical students scored high scores and responded to the questions 
answered that they would like to stay in their group, as well as highly appreciated the relationship between members of their group.

Conclusions. Thus, the socio-psychological climate is a psychological mood in a group that reflects the nature of the relationship between people. The favorable atmosphere in the group not only productively affects its results, but also rebuilds the person, creates new opportunities and shows potential. In connection with this, there is a need to optimize the style of interpersonal interaction among medical students.

KEY WORDS: psychological climate; team; factors; factors psychological climate.

Рукопис надійшов до редакції 03.11.2017 р.

Відомості про автора:

Ленчук Тетяна Любомирівна - доцент кафедри радіології та радіаційної медицини ДВНЗ «Івано-Франківський національний медичний університет»; тел.: +38(067) 887-21-14. 